\title{
Pengaruh Mutu Produk, Pengetahuan Konsumen, terhadap Proses Keputusan Financing Murabahah Bank Islam serta Dampaknya terhadap Kepuasan Sebuah Survey di Bandung
}

\author{
Rizkha Afriani \\ Manajemen \\ rizkha·kireidesu@gmail.com
}

\begin{abstract}
Abstrak Indonesia merupakan Negara yang berpenduduk muslim terbesar di dunia, dan Bandung menjadi salah satu provinsi yang terdapat penduduk muslim yang terbesar di Indonesia. Penelitian ini bertujuan untuk memberikan informasi mutu produk dan pengetahuan Islamic Bank pada akad murabahah terhadan keputusan financing serta dampaknya terhadap kepuasan masyarakat muslim yang ada di kota bandung. Data dikumpulkan melalui metode kuesioner terhadap 177 orang responden mengunakan metode purposive sampling untuk mengetahui tanggapan responden terhadap masing-masing variabel. Kemudian dilakukan analisis terhadap data-data yang diperoleh berupa analisis kuantitatif dan analisis kualitatif. Teknik analisis data yang digunakan adalah analisis regersi linear berganda dan regresi sederhana yang berfungsi untuk membuktikan hipotesis penelitian. Pada pengujian regresi linear berganda data-data yang telah memenuhi uji validitas, uji reliabilitas, dan uji asumsi klasik diolah sehingga menghasilkan analisis bahwa faktor mutu produk, pengetahuan memiliki pengaruh positif dan signifikan terhadap proses Keputusan Pembelian. Sedangkan pada regresi sederhana menghasilkan analisis bahwa keputusan pembelian berpengaruh positif dan signifikan terhadap Kepuasan Pelanggan.
\end{abstract}

Kata Kunci Mutu Produk, Pengetahuan konsumen, proses Keputusan Pembelian, Murabahah Islamic Banking, Kepuasan

\section{PENDAhuluan}

Krisis ekonomi global yang terjadi sejak tahun 1998, Indonesia juga terkena dampak ekonomi yang menurun, hal ini ditandai dengan naiknya harga semua barang dari tahun ketahun dan turunnya mata uang Indonesia yaitu Rupiah sejak tahun 1998. Dalam hal ini, Lembaga Keuangan Bank dianggap sebagai salah satu pendongkrak laju pertumbuhan ekonomi global termasuk Indonesia. Pada saat terjadinya krisis ekonomi global tersebut maka bank konvensional dianggap kurang mampu menunjukan eksistensinya dalam meningkatkan laju pertumbuhan ekonomi karena inflasi yang terjadi terus menerus di seluruh negara. Dari sinilah kebangkitan perbankan syariah terjadi di negara Indonesia dan beberapa negara maju lainnya. Berdasarkan laporan dari International Association of Islamic Banks dan analisis Khursid Ahmad menyebutkan bahwa hingga tahun 1999 telah terdapat lebih dari 200 lembaga keuangan Islam yang beroperasi di seluruh dunia, yaitu di negara-negara dengan mayoritas penduduk muslim serta negara-negara lainnya di Eropa, Australia, maupun Amerika(Khursid Ahmad, 1999)

Apabila dipandang dari sudut global Indonesia sebagai negara dengan penduduk muslim terbesar, sudah selayaknya menjadi pelopor dan kiblat pengembangan keuangan syariah di dunia. Akan tetapi pada faktanya berdasarkan Islamic Finance Country Index (IFCI) 2011-2013, Indonesia hanya mendapat peringkat 5 dalam index yang dapat ditunjukan pada gambar 1.1 dibawah ini: 


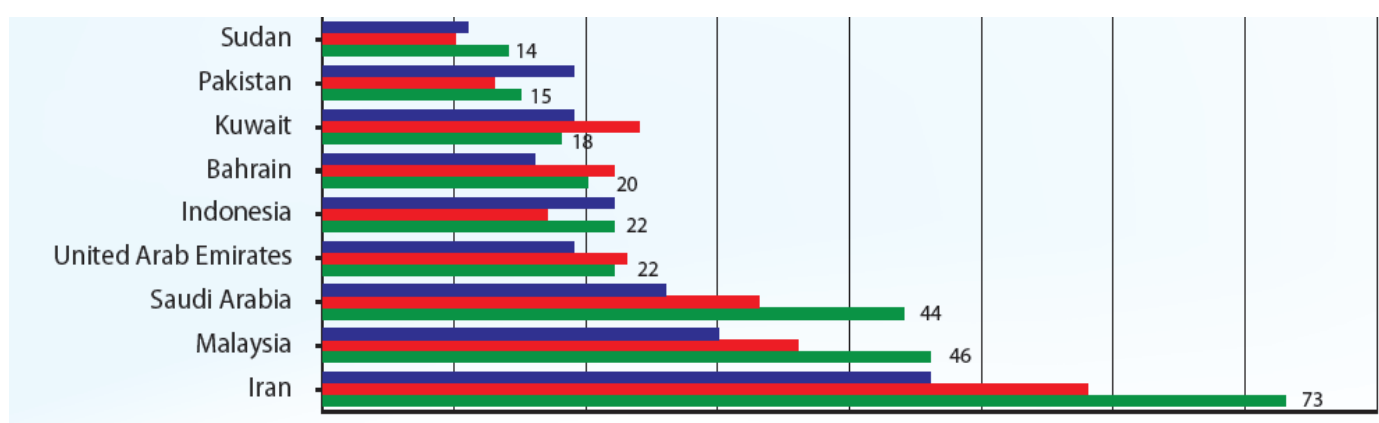

Keterangan :

Sumber :Islamic Finance Country Index (IFCI) 2011-2013

Gambar 1.1 Grafik Indeks Keuangan Islam Beberapa Negara (Islamic Finance Country Index (IFCI) 2011-2013)

Apabila dilihat dari laporan BI tahun 2012, Pertumbuhan aset perbankan syariah pada akhir tahun 2012 yang mencapai $\pm 34 \%$ (yoy), dan pertumbuhan pembiayaan yang tetap tinggi yang mencapai $\pm 44 \%$ (yoy) dengan NPF gross perbankan syariah (BUS+UUS) yang terkendali, merupakan beberapa contoh masih tetap terjaganya kinerja perbankan syariah Indonesia. Walaupun sepanjang tahun 2012 dampak krisis keuangan global cenderung melambatkan laju pertumbuhan ekonomi di berbagai negara, namun memiliki pengaruh yang relatif minimal terhadap industri perbankan syariah nasional, yang terlihat antara lain dari pertumbuhan volume usaha perbankan syariah yang relatif masih cukup tinggi. Meskipun mengalami peningkatan volume usaha perbankan syariah, hal tersebut bukanlah sesuatu yang dapat dibanggakan bagi negara Indonesia karena sebagai negara berstatus muslim terbesar di dunia yang sudah mendirikan perbankan syariah dari tahun 1992 ternyata di tahun 2011 hanya mendapat populasi 621.110 jiwa yang membuka rekening di bank syariah (hasil riset Mars Indonesia 2011 bersumber dari newsletter mars Indonesia 2014). Dari sudut pemasaran maka hal ini dapat dikatakan adanya indikasi untuk meningkatkan kepuasan nasabah perbankan syariah terhadap keputusan membeli atas produk (funding, financing dan jasa) yang dijual Bank Islam Indonesia.

Riset ini mencoba melakukan investigasi dari sisi mutu produk, pengetahuan dan financing murabahah perbankan Islam terhadap keputusan penggunaan (keputusan pembelian) jasa Bank Islam dan dampaknya bagi kepuasandi Bandung.

\section{Perumusan Masalah}

1. Bagaimanapengaruh mutu produk, pengetahuan, terhadap proses keputusan pembelian financing murabahah secara simultan dan parsial pada bank Islam di kota Bandung?

2. Bagaimana pengaruh proses keputusan pembelian terhadap kepuasan bank Islam di kota Bandung?

\section{LANDASAN TEORI}

Pengertian Bank Islam (Bank Syariah)

Pengertian bank berdasarkan undang-undang yang diatur di Indonesia tahun 2008 No 21 pada pasal 2 berisi "bank adalah badan usaha yang menghimpun dana dari masyarakat dalam bentuk Simpanan dan menyalurkannya kepada masyarakat dalam bentuk kredit dan/atau bentuk lainnya dalam rangka meningkatkan taraf hidup rakyat."

Pemerintah Indonesia juga menerbitkan undang-undang dan peraturan pemerintah sebagai aturan main perbankan syariah. Dalam undang-undangnya tahun 2008 dalam Ketentuan Umum Pasal 1 Ayat 7, ditegaskan: "Bank syariah adalah bank yang menjalankan kegiatan usahanya berdasarkan prinsip syariah dan menurut jenisnya terdiri atas Bank Umum Syariah (BUS) dan Bank Pembiayaan Rakyat Syariah (BPRS)." Pada Bab 2 Pasal 2 dinyatakan: "Perbankan syariah dalam 
melakukan kegiatan usahanya berasaskan prinsip syariah, demokrasi ekonomi, dan prinsip kehatihatian."

\section{Mutu Produk Bank Islam}

Produk adalah semua yang bisa ditawarkan dipasar untuk mendapatkan perhatian, permintaan, pemakaian atau konsumsi yang dapat memenuhi keinginan atau kebutuhan konsumen (Sumarni dan Supranto, 1997 dalam Tjiptono, 2006:95).

Berdasarkan pada ketentuan peraturan Bank Indonesia No. 7/46/PBI/2005 tentang akad perhimpunan dan penyaluran dana bagi bank yang melaksanakan kegiatan usaha berdasarkan prinsip syariah, sebagaimana telah dicabut melalui PBI No.9/19/PBI/2007 tentang pelaksanaan prinsip syariah dalam kegiatan perhimpunan dana dan penyaluran dana serta pelayanan jasa bank syariah kemudian dirubah dengan PBI No.10/16/PBI/2008 secara garis besar produk-produk perbankan syariah terdiri dari:

1. Produk bank syariah yang di dasarkan pada akad jual beli adalah sebagai berikut:

a. Murabahah, adalah jual beli barang sebesar harga pokok barang ditambah dengan margin keuntungan yang disepakati.

b. Istishna, adalah jual barang dalam bentuk pemesanan pembuatan barang dengan kriteria dan persyaratan tertentu yang disepakati dengan pembayaran sesuai dengan kesepakatan.

c. Salam, adalah jual beli barang dengan pemesanan dengan syarat-syarat tertentu dan pembayaran tunai terlebih dahulu secara penuh.

Kualitas produk mencerminkan kemampuan produk untuk menjalankan tugasnya yang mencakup daya tahan, kehandalan, kemajuan, kekuatan, kemudahan dalam pengemasan, dan reparasi produk dan ciri-ciri lainnya (Kotler dan Armstrong, 2001:279).

\section{Pengertian Pengetahuan Konsumen (Consumer knowledge)}

Mowen and Minor (1998: 106) mendefinisikannya sebagai :

"The amount of experience with and information about particular produts or services a person has". Sedangkan Engel et al. (1994: 337) : "at a general level, knowledge can be defined as the information stored within memory. The subset of total information relevant to consumers functioning in the marketplace is called consumer knowledge".

Pengetahuan seseorang tentang lingkungan konsumsi disimpan dalam memori yang panjang, dimana merupakan bahan informasi bagi setiap konsumen. Hoyer dan Maclnnis (2008 : 92) pengetahuan dapat didefinisikan sebagai informasi yang disimpan di dalam ingatan. "Himpunan bagian dari informasi total yang relevan dengan fungsi konsumen di dalam pasar disebut pengetahuan konsumen".Asumsinya adalah bahwa pengalaman yang lebih banyak akan terwujud ke dalam pengetahuan yang lebih luas.

Menurut Hoyer dan Maclnnis (2008:92) dalam pengetahuan konsumen, ada dua domain utama dari pengetahuan yaitu : Isi pengetahuan / pengetahuan konten (informasi yang disimpan) dan struktur pengetahuan.

Berdasarkan kepada ketiga definisi tersebut dapat diartikan bahwa pengetahuan konsumen adalah semua informasi yang dimilki konsumen mengenai berbagai macam produk dan jasa, serta pengetahuan lainnya yang terkait dengan produk dan jasa tersebut dan informasi yang berhubungan dengan fungsinya sebagai konsumen.

\section{Keputusan Pembelian}

Pengambilan keputusan diawali dengan adanya kebutuhan yang berusaha untuk dipenuhi. Pemenuhan kebutuhan ini terkait dengan beberapa alternatif sehingga perlu dilakukan evaluasi yang bertujuan untuk memperoleh alternatif terbaik dari persepsi konsumen. Kotler dan Keller (2012: 214) menjelaskan bahwa proses pengambilan keputusan merupakan proses psikologis dasar yang memainkan peranan penting dalam memahami bagaimana konsumen secara aktual 
mengambil keputusan pembelian. Titik awal untuk memahami perilaku konsumen adalah model rangsangan-tanggapan.

Sebagaimana telah dikatakan sebelumnya bahwa pengambilan keputusan merupakan suatu proses, pada bagian ini akan diuraikan beberapa pendapat terkait tahapan-tahapan yang dilakukan. Berikut ini adalah gambar model proses pengambilan keputusan menurut McShane dan Glinow (2012):

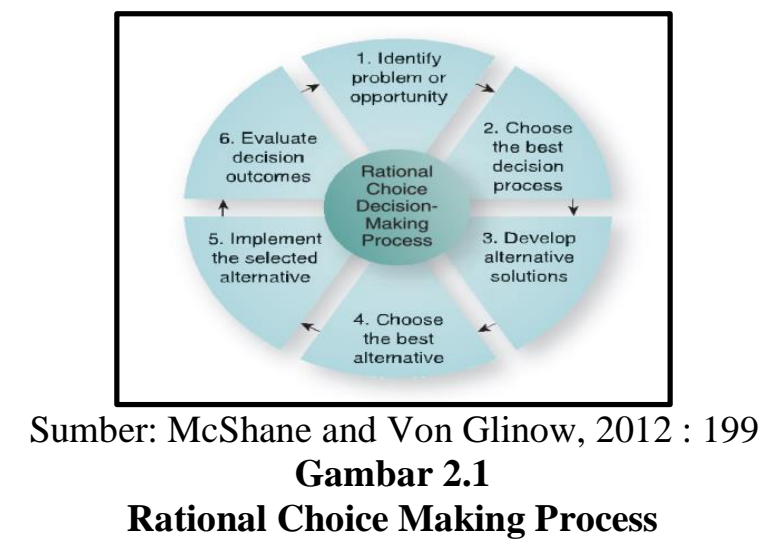

Dari gambar di atas, langkah pertama adalah mengidentifikasi 'masalah' atau mencari 'peluang'. Masalah adalah deviasi antara kenyataan dan situasi yang diharapkan (gap antara 'apa yang terjadi' dan 'apa yang seharusnya terjadi'). Sedangkan peluang adalah deviasi antara harapan saat ini dan situasi potensial yang lebih baik dimana sebelumnya belum diharapkan. Dengan kata lain, pemngambil keputusan menyadari bahwa beberapa keputusan membuat hasilnya berdasarkan tujuan saat ini atau harapan. Langkah kedua, melibatkan keputusan bagaimana memproses keputusan. Salah satu isu terkait dengan hal ini adalah apakah pengambil keputusan memiliki informasi yang cukup atau memerlukan yang lainnya terlibat di dalam proses. Ketiga, mengidentifikasi dan mengembangkan daftar solusi yang memungkinkan.

Langkah keempat dalam proses keputusan rasional adalah memilih alternatif dengan subjective expected utility paling tinggi. Inilah prinsip paling pokok dalam cara pandang pilihan rasional yang diartikan sebagai kemungkinan (harapan) dari kepuasan (kegunaan) yang dihasilkan dari memilih alternatif yang spesifik dalam keputusan. Langkah kelima adalah mengimplementasikan alternatif yang telah dipilih. Kemudian diiringi dengan langkah yang terkahir, keenam, yaitu evaluasi apakah gap yang muncul mendekati antara 'apa yang terjadi' dan 'apa yang harusnya terjadi'.

\section{Kepuasan Pelanggan}

Kepuasan pelanggan yaitu respon atau tanggapan yang diberikan para konsumen setelah terpenuhinya kebutuhan mereka akan sebuah produk ataupun jasa, sehingga para konsumen memperoleh rasa nyaman dan senang karena harapannya telah terpenuhi. Selain itu kepuasan pelanggan juga sering dijadikan sebagai salah satu tujuan utama dari strategi pemasaran bisnis, baik bisnis yang dijalankan dengan memproduksi barang maupun bisnis jasa.Kepuasan disini mencerminkan penilaian seseorang tentang kinerja produk anggapannya (atau hasil) dalam kaitannya dengan harapan. apabila kinerja tersebut tidak memenuhi harapan maka pelanggan tidak puas. Jika kinerja sesuai dengan ekspetasi, pelanggan puas. jika kinerja melebihi ekspetasi maka pelanggan tersebut senang. (Kotler dan Keller 2009:14)

Dengan adanya penilaian kepuasan pelanggan pemasar dapat mengetahui kebutuhan yang diinginkan para pelanggan. Yang berpengaruh pula terhadap omset penjualan produk. Untuk itu berikan pelayanan prima bagi setiap pelanggan, agar pelanggan merasa senang dan nyaman dengan produk pemasar. Bagi bisnis, kepuasan pelanggan dipandang sebagai salah satu dimensi kinerja pasar. Penigkatan kepuasan pelanggan berpotensi mengarah pada pertumbuhan penjualan 
jangka panjang dan jangka pendek, serta pangsa pasar sebagai hasil pembelian ulang. Sementara itu ketidakpuasan pelanggan memunculkan sejumlah risiko, seperti boikot atau protes dari lembaga konsumen, intervensi pemerintah, reaksi pesaing, dan maraknya produk subsititusi baru ke pasar (Tjiptono dkk, 2008).

\section{Kerangka Penelitian}

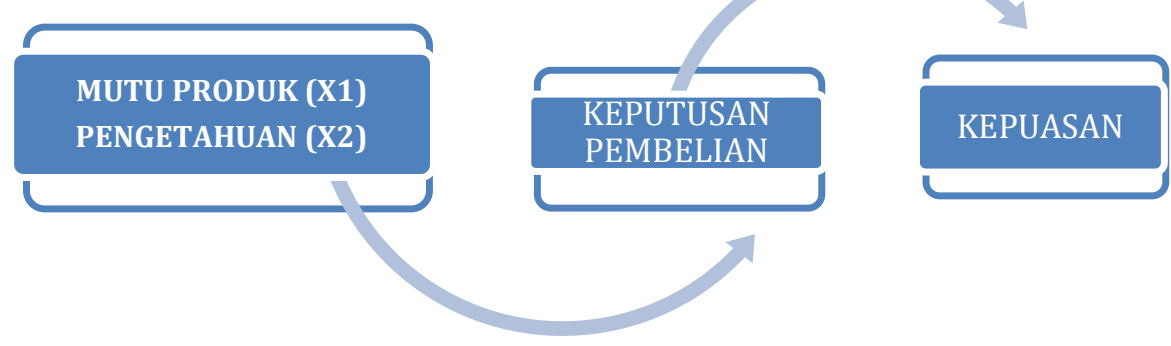

\section{Hipotesis}

- Hipotesis 1: Kualitas produk (X1) Pengetahuan (X2), berpengaruh positif dan signifikan secara simultan dan parsial terhadap Keputusan Pembelian (Y)

- Hipotesis 2: Proses Keputusan Pembelian (Y) berpengaruh positif dan signifikanterhadap kepuasan Pelanggan (Z).

\section{METODOLOGI PENELITIAN}

Penelitian ini berjenis penelitian deskriptif dan verifikatif. Penelitian deskriptif digunakan untuk menjelaskan dan memberikan gambaran dari variabel yang diteliti, yaitu: Mutu produk, pengetahuan,proses pengambilan keputusan dan kepuasan . Sedangkan penelitian verifikatif digunakan dalam penelitian tesisi ini untuk mengetahui hubungan antar variabel-variabel tersebut melalui suatu pengujian hipotesis.

Pengumpulan data diperoleh dari lapangan, dengan demikian metode yang digunakan adalah metode survey yaitu suatu pengumpulan data yang dilakukan terhadap suatu objek di lapangan dengan mengambil sampel dari suatu populasi dan menggunakan kuesioner sebagai alat pengumpulan data primer. Secara waktu, penelitian ini bersifat cross sectional, artinya objek dipelajari dalam satu kurun waktu tertentu saja atau tidak berkelanjutan dalam jangka waktu yang panjang

Penetapan jumlah sampel dengan tingkat signifikan 5\% dan tingkat kesalahan yang dapat ditoleransi sebesar 5\% adalah sebagai berikut :

$$
\begin{gathered}
n=\left(1,96^{2}\right) \frac{13,3 x 86,7}{5^{2}} \\
n=177,19^{5^{2}}
\end{gathered}
$$

Maka jumlah pengguna yang akan dijadikan sampel dalam penelitian ini adalah 177 orang. Kriteria yang ditetapkan yaitu responden beragama islam yang memiliki penghasilan perbulan.

\section{Pengujian Hipotesis}

\subsubsection{Uji Serempak/Uji F}

Uji $F$ digunakan untuk menguji hipotesis nol bahwa koefisien determinasi majemuk dalam populasi, $R 2$, sama dengan nol. Uji signifikansi meliputi pengujian signifikansi persamaan regresi secara keseluruhan serta koefisien regresi parsial spesifik. Uji keseluruhan dapat dilakukan dengan menggunakan statistik $F$. 
Statistik uji ini mengikuti distribusi $F$ dengan derajat kebebasan $k$ dan (nk- 1) (Malhotra, 2006: 200). Jika hipotesis nol keseluruhan ditolak, satu atau lebih koefisien regresi majemuk populasi mempunyai nilai tak sama dengan 0 . Uji $F$ parsial meliputi penguraian jumlah total kuadrat regresi Ssreg menjadi komponen yang terkait dengan masing-masing variabel independen.

\section{HASIL PENELITIAN \\ Pengujian Hipotesis \\ Pengujian Hipotesis Pertama \\ Uji F}

Untuk menguji hipotesis ini digunakan statistik $\mathrm{F}$ dengan kriteria pengambilan keputusan jika nilai Fhitung lebih besar dari Ftabel, maka H0 ditolak dan H1 diterima. Pengaruh secara serempak variabel Mutu produk, pengetahuan, dan dapat dilihat pada Tabel 4.19 yaitu :

Tabel 4.12

Uji F Untuk Hipotesis Pertama ANOVA $^{\mathrm{a}}$

\begin{tabular}{|ll|r|r|r|r|r|}
\hline Model & Sum of Squares & Df & Mean Square & F & Sig. \\
\hline \multirow{2}{*}{ Regression } & 1694,271 & 4 & 423,568 & 100,310 &, $000^{\mathrm{b}}$ \\
Residual & 726,283 & 172 & 4,223 & & \\
Total & 2420,554 & 176 & & & \\
\hline
\end{tabular}

a. Dependent Variable: Proses_Keputusan

b. Predictors: (Constant), Pengetahuan, Mutu_produk

Sumber : Hasil Pengolahan data SPSS 20 (2014)

Berdasarkan Tabel 4.12 dapat diketahui bahwa F hitung $=100,310$ dan $\mathrm{F}$ tabel $=2,42$. Artinya $\mathrm{F}$ hitung lebih besar dari $\mathrm{F}$ tabel dan nilai signifikan adalah 0,000 lebih kecil dari alpha 0,05. Sehingga keputusan yang diambil adalah H0 ditolak dan H1 diterima. Hal ini berarti semua variabel independen (mutu produk, pengetahuan, dan ) mempunyai pengaruh yang signifikan secara simultan terhadap variabel dependen (proses keputusan membeli) atau dapat dikatakan bahwa variabel independen yaitu, mutu produk, pengetahuan, mampu menjelaskan proses keputusan meminjam akad murabahah padamasyarakat muslim yang ada di Bandung.

\subsubsection{Pengujian Hipotesis Kedua}

\subsection{Uji F}

Untuk menguji hipotesis ini digunakan statistik $\mathrm{F}$ dengan kriteria pengambilan keputusan jika nilai Fhitung lebih besar dari Ftabel, maka H0 ditolak dan H1 diterima. Pengaruh secara serempak variabel proses keputusan terhadap kepuasan dapat dilihat pada Tabel 4.23 yaitu:

Tabel 4.16

Uji F untuk Hipotesis Kedua ANOVA $^{\mathrm{a}}$

\begin{tabular}{|c|c|c|c|c|c|}
\hline Model & $\begin{array}{c}\text { Sum of } \\
\text { Squares }\end{array}$ & $\overline{\mathrm{Df}}$ & Mean Square & $\mathrm{F}$ & Sig. \\
\hline Regression & 276,829 & 1 & 276,829 & 52,197 &, $000^{\mathrm{b}}$ \\
\hline Residual & 928,120 & 175 & 5,304 & & \\
\hline Total & 1204,949 & 176 & & & \\
\hline
\end{tabular}

a. Dependent Variable: Kepuasan

b. Predictors: (Constant), Proses_Keputusan

Sumber : Hasil Pengolahan data SPSS 20 (2014)

Berdasarkan Tabel 4.16 dapat diketahui bahwa F hitung $=52,197$ dan $\mathrm{F}$ tabel $=3,90$. Artinya $\mathrm{F}$ hitung lebih besar dari $\mathrm{F}$ tabel dan nilai signifikan adalah 0,000 lebih kecil dari alpha 0,05. 
Sehingga keputusan yang diambil adalah H0 ditolak dan H1 diterima. Hal ini berarti semua variabel independen (proses keputusan) mempunyai pengaruh yang signifikan secara simultan terhadap variabel dependen (kepuasan) atau dapat dikatakan bahwa variabel independen yaitu, proses keputusanmampu menjelaskan kepuasan.

\section{Pembahasan \\ Hipotesis 1}

1. Berdasarkan konsep dari teori sebelumnya menyatakan bahwa Mutu produk bank Islam sebagai faktor internal yang mempengaruhi keputusan pembelian (Rina Astini, 2011, , Pajaree Ackaradejruangsr 2013), sedangkan hasil penelitian yang terdapat pada uji serempak (uji F) secara simultan mutu produk sangat berpengaruh signifikan terhadap proses keputusan, sedangkan hasil dari uji t atau uji parsial terdapat tanda non signifikan 0,000 lebih besar dari alpha 0,05 artinya secara parsial mutu produk tidak terlalu berpengaruh terhadap proses keputusan meminjam di Bank Islam.

2. Berdasarkan konsep dari teori sebelumnya menyatakan Pengetahuan dapat memiliki dampak yang kuat pada pengambilan keputusan. (Alba dan Hutchinson 1987; Brucks 1986), ), Rizal Setyawan (2010) Diawati, Prety (2012) pada uji serempak (uji F) secara simultan pengetahuan sangat berpengaruh signifikan terhadap proses keputusan, sedangkan hasil dari uji $t$ atau uji parsial terdapat tanda signifikan 0,000 lebih kecil dari alpha 0,05 artinya secara parsial pengetahuan berpengaruh terhadap proses keputusan meminjam di Bank Islam. Sehingga dapat dikatakan bahwa pengetahuan masyarakat mengenai produk bank Islam, pengetahuan saat pembelian serta pengetahuaan pemakaian produk sangat mempengaruhi masyarakat muslim dalam mengambil proses keputusan untuk jadi pelanggan, meskipun apabila dilihat secara deskriptif pengetahuan masyarakat muslim di Bandung hanya sekitar $42,8 \%$ yang mengetahui tentang produk jual beli dengan akad murabaha Bank Islam..

\section{Hipotesis 2}

Keputusan kepuasan merupakan isu penting yang telah diperiksa dalam psikologi dan penelitian keputusan. Namun, penelitian kepuasan telah terutama difokuskan pada kepuasan dengan pilihan dan hasil dari proses pengambilan keputusan (Oliver, 1980), dan telah mengabaikan pentingnya kepuasan dengan proses pengambilan keputusan. Namun, daerah sastra telah dikembangkan untuk mempelajari kepuasan dengan proses pengambilan keputusan (Fitzsimons, Greenleaf dan Lehmann, 1997; Fitzsimons, 2000; Iyengar dan Lepper, 2000). Pengalaman proses keputusan "dipengaruhi oleh variabel yang membentuk situasi di mana terjadi keputusan" (Zhang dan Fitzsimons, 1999). Oleh karena itu kepuasan dengan proses tersebut secara konseptual berbeda dari kepuasan dengan pilihan dan dimensi yang mendasari mereka lbervariasi. (Supadiyono, Agus (2008), Karimi (2013))

Berdasarkan hasil penelitian ini $\mathrm{F}$ hitung lebih besar dari $\mathrm{F}$ tabel dan nilai signifikan adalah 0,000 lebih kecil dari alpha 0,05. Sehingga keputusan yang diambil adalah H0 ditolak dan H1 diterima. Hal ini berarti semua variabel independen (proses keputusan) mempunyai pengaruh yang signifikan secara simultan terhadap variabel dependen (kepuasan) atau dapat dikatakan bahwa variabel independen yaitu, proses keputusanmampu menjelaskan kepuasan. nilai signifikan 0,000 lebih kecil dari nilai alpha 0,05 $(0,000<0,05)$, sehingga dapat dikatakan $\mathrm{H} 0$ ditolak dan $\mathrm{H} 1$ diterima untuk variabel proses keputusan, artinya variabel proses keputusan mempengaruhi secara signifikan terhadap kepuasan. 


\section{KESIMPULAN}

1. Mutu produk pada uji serempak (uji F) secara simultan mutu produk sangat berpengaruh signifikan terhadap proses keputusan, sedangkan hasil dari uji t atau uji parsial terdapat tanda non signifikan 0,000 lebih besar dari alpha 0,05 artinya secara parsial mutu produk tidak terlalu berpengaruh terhadap proses keputusan meminjam di Bank Islam.

2. Pengetahuan pada uji serempak (uji F) secara simultan pengetahuan sangat berpengaruh signifikan terhadap proses keputusan, sedangkan hasil dari uji t atau uji parsial terdapat tanda signifikan 0,000 lebih kecil dari alpha 0,05 artinya secara parsial pengetahuan berpengaruh terhadap proses keputusan meminjam di Bank Islam. Sehingga dapat dikatakan bahwa pengetahuan masyarakat mengenai produk bank Islam, pengetahuan saat pembelian serta pengetahuaan pemakaian produk sangat mempengaruhi masyarakat muslim dalam mengambil proses keputusan untuk jadi pelanggan, meskipun apabila dilihat secara deskriptif pengetahuan masyarakat muslim di Bandung hanya sekitar 42,8\% yang mengetahui tentang produk jual beli dengan akad murabaha Bank Islam.

3. pada uji serempak (uji F) secara simultan sangat berpengaruh signifikan terhadap proses keputusan, sedangkan hasil dari uji t atau uji parsial terdapat terdapat tanda signifikan 0,000 lebih kecil dari alpha 0,05 artinya secara parsial berpengaruh terhadap proses keputusan meminjam di Bank Islam. Dengan kata lain umur, pekerjaan, situasi ekonomi, gaya hidup dan kepribadian atau konsep diri masyarakat muslim di Bandung sangat mempengaruhi proses keputusan mereka untuk menjadi pelanggan di Bank Islam.

4. Pada uji serempak (uji F) secara simultan sangat berpengaruh signifikan terhadap proses keputusan, sedangkan hasil dari uji t atau uji parsial terdapat tanda tanda signifikan 0,000 lebih kecil dari alpha 0,05 artinya secara parsial berpengaruh terhadap proses keputusan meminjam di Bank Islam. Dengan kata lain motivasi, persepsi, pembelajaran, keyakinan dan sikap masyarakat muslim di Bandung sangat mempengaruhi proses keputusan mereka untuk menjadi pelanggan di Bank Islam.

\section{DAFTAR PUSTAKA}

Ackaradejruangsr, Pajaree 2013 , The effect of product quality attributes on Thai consumers' buying decisions Ritsumeikan Journal of Asia Pacific Studies Volume 33, 2013

Agung Purwo Atmojo (Skripsi 2010) Analisis Pengaruh Kualitas Layanan, Nilai Nasabah, Dan Atribut Produk Islam Terhadap Kepuasan Nasabah (Studi Kasus Pada BNI Syariah Cabang Semarang)

Anber Abraheem Shlash Mohammad, Shireen Yaseen Mohammad Alhamadani (2011) Service Quality Perspectives and Customer Satisfaction inCommercial Banks Working in Jordan

Anshori, Abdul Ghofur, 2009. Perbankan Syariah di Indonesia, Gajah Mada University Press, Yokyakarta.

Diawati, Prety, 2012, Pengaruh Motivasi Dan PengetahuanKonsumen Terhadap Keputusan Menjadi Nasabah Pada Bank Syariah (Survei Pada Nasabah Pt.Bank Syariah Bukopin Kantor Cabang Bandung)

Durmaz Yakup \&Sebastian Jablonsk (2012) Integrated Approach to Factors Affecting Consumers PurchaseBehavior in Poland and an Empirical Study Global Journal of Management and Business ResearchVolume 12 Issue 15 Version 1.0 Year 2012 
Durmaz, Yakup(2014)The Impact of Psychological Factors on Consumer Buying Behavior and an Empirical Application in Turkey, Asian Social Science; Vol. 10, No. 6; 2014

Ghozali Maski (2010) Analisis Keputusan Nasabah Menabung: Pendekatan Komponen Dan Model Logistik Studi Pada Bank Syariah Di Malang

Joseph W. Alba and Howard The Effects of Frequency Knowledge on Consumer Decision Making Author(s): Marmorstein Source: The Journal of Consumer Research, Vol. 14, No. 1 (Jun., 1987), pp. $14-25$

Karimi, Sahar,2013, A purchase decision-making process model of online consumers and its influential factor a cross sector analysis A Thesis submitted to the University of Manchester for the degree of PhD In the Faculty of Humanities

Kotler, Philip. 2012. Manajemen Pemasaran . Erlangga, Jakarta

2014. Principles of Marketing fifhteen edition, Pearson

Khursid Ahmad, Islamic Finance and Banking: The Challenge of the $21^{\text {st }}$ Century, dalam Imtiyazuddin Ahmad (ed.) Islamic Banking and Finance: The Concept, The Practice and The Challenge (Plainfield: The Islamic Society of North America, 1999).

Rina Astini (skripsi 2011) Analisis Pengaruh Kualitas Produk Tabungan Dan Word of Mouth Terhadap Keputusan Pembelian Nasabah (Studi Kasus: Nasabah Tabungan Monas Kantor Pusat PT Bank DKI

Sugiyono, 2008. Metode Penelitian Bisnis, Alfabeta, Bandung.

Sula, Atik Emilia ,2010, Reformulasi Akad Pembiayaan Murabahah Dengan Sistem Musyarakah Sebagai Inovasi Produk Perbankan Syariah Universitas Trunojoyo Madura

Suliyanto, 2006. Metode Riset Bisnis, Andi, Yogyakarta.

Supadiyono, Agus (Tesis 2008) Pengaruh Nilai Pelanggan (customer Value) terhadap keputusan Pembelian Produk dengan Kepuasan sebagai Variabel Moderasi

Supramono, 2005. Desain Proposal Penelitian Studi Pemasaran, Andi, Yokyakarta.

Sutisna. 2003. Perilaku Konsumen dan Komunikasi Pemasaran, Remaja Rosdakarya, Bandung.

Tarmizi, Erwandi, 2012. Harta Haram Muamalat Kontemporer, Berkat Mulia Insani, Bogor.

Tjiptono, Fandy, Gregorius Chandra dan Dadi Adriana. 2008. Pemasaran Strategik, Andi, Yogyakarta.

Bank Indonesia, diupload tanggal 11 November 2013, http://bi.go.id Islamic Finance Country Index (IFCI) 2011-2013, di upload tanggal 02 Maret 2014, 